\title{
Establishment and Characterization of a Novel Human Monocytic Leukemia Cell Line (KP-1) Expressing Scavenger Receptor
}

\author{
NAOTO ADACHI, KAZUTAKA TAKAKI, RIE NAKAMURA, TAKAO OHTA, MAKOTO NAITO, \\ SEIKOH HORIUCHI, AND ICHIRO MATSUDA \\ Department of Pediatrics [N.A., R.N., T.O., I.MI.], Second Department of Biochemistry [S.H.J, Kumamoto \\ University School of Medicine, and Department of Pediatrics, National Kumamoto Hospital [K.T.J, Kumamoto \\ City, Kumamoto, and Second Department of Pathology [M.N.]. Niigata University School of Medicine. \\ Niigata City, Japan
}

\begin{abstract}
A new monocytic leukemia cell line (KP-1) was established from a 2-y-old Japanese girl with acute monocytic leukemia. The KP-1 cells were maintained in suspension culture with a doubling time of $96 \mathrm{~h}$. The cells were positively stained with $\alpha$-naphtyl butyrate esterase, but not with naphthol AS-D chloroacetate esterase, myeloperoxidase, and periodic acid-Schiff reagent. Cell surface marker analysis revealed that the cells were CD4, CD11a, CD11c, CD13, CD14, CD18, CD33, and HLA-DR positive. Karyotype analysis revealed near diploidy (47 XX) and a translocation $t(11 ; 19)$ was found. When treated with 12-o-tetradecanoylphorbol 13-acetate, KP-1 cells became tightly adherent, showed the enhanced reactivity for $\alpha$ naphtyl butyrate esterase, and produced several monokines such as IL-1 $\beta$, tumor necrosis factor- $\alpha$, and macrophage colony-stimulating factor. Immunoelectron microscopy demonstrated that the human macrophage scavenger receptor was expressed after 12-0-tetradecanoylphorbol13-acetate treatment, and the cells accumulated a large amount of cholesterol esters in the presence of acetylated LDL. Compared with another human monocytic leukemia cell line, THP-1, KP-1 expressed scavenger receptor and accumulated cholesterol ester more rapidly in the presence of 12-0-tetradecanoyl phorbol-13-acetate and acetylated LDL. Scatchard analysis using ${ }^{125}$ I-labeled acetylated LDL revealed a typical saturation curve with an apparent $\mathbf{k}_{\mathbf{d}}$ of $1.7 \times 10^{-7} \mathrm{M}$ and 3400 binding sites per cell. KP-1 retained the characteristics of monocyte-macrophage lineage cells and will facilitate the in vitro studies of the pathologic and physiologic roles of scavenger receptors. (Pediatr Res 34: 258-264, 1993)
\end{abstract}

\section{Abbreviations}

TPA, 12-0-tetradecanoylphorbol-13-acetate

$\mathrm{CE}$, cholesterol ester

aLDL, acetylated LDL

TNF, tumor necrosis factor

PDGF, platelet-derived growth factor

FBS, fetal bovine serum
M-CSF, macrophage colony-stimulating factor

Macrophages have been shown to be involved in a number of physiologic processes including presentation of antigens to $T$ and $\mathrm{B}$ lymphocytes, resistance to intracellular parasites and bacteria, tumor immunity, and phagocytosis of foreign materials. In addition to these physiologic functions, the pathologic role of macrophages in the atherosclerotic process is highlighted because the foam cells that characterize the early stage of atherosclerotic lesions have been demonstrated to express several macrophagerelated phenotypes (1-3). It is generally accepted at present that most of the foam cells in the early stage of atherosclerotic lesions are derived from the circulating monocytes, which differentiate in the subendothelial space to macrophages and are transformed into foam cells in the presence of modified LDL.

Goldstein et al. (4) demonstrated that macrophages in culture do not accumulate a large amount of $C E$ if cultured with the native LDL, but if chemically modified LDL such as aLDL is used, the foam cell formation occurs. This result indicates that the uptake of aLDL is mediated by a receptor distinct from the LDL receptor, called the scavenger receptor. Recently, Matsumoto et al. (5) succeeded in the molecular cloning of cDNA for the human macrophage scavenger receptor. Then, Freeman $e t$ al. (6) demonstrated that transfection of cDNA of the scavenger receptor to Chinese hamster ovary cells leads to their conversion to foam-like cells in the presence of modified LDL. Furthermore, several investigators reported that scavenger receptor mRNA and protein have been detected in foam cells in atherosclerotic plaques in vivo. $(5,7)$. These studies indicate that the scavenger receptor pathway plays an important role in the foam cell formation in vitro and in vivo.

The scavenger receptors are speculated to be involved in other physiologic responses because of their broad binding specificity. In fact, Hampton et al. (8) demonstrated that bacterial endotoxin is a ligand of scavenger receptor and hepatic uptake of endotoxin by this receptor plays a significant role in endotoxin clearance. Thus, the scavenger receptor is speculated to play some important, physiologic roles in vivo.

Here we report the establishment and characterization of a novel human monocytic leukemia cell line (KP-1) with special reference to the characterization of the scavenger receptor. After TPA treatment, this cell line can be differentiated into mature macrophage-like cells that share many characteristics with normal macrophages.

\section{MATERIALS AND METHODS}

Received February 3, 1993; accepted April 26, 1993.

Correspondence and reprint requests: Dr. Naoto Adachi, Department of Pediatrics, Kumamoto University School of Medicine, Honjo 1-1-1, Kumamoto City, Kumamoto 860, Japan.

Supported in part by the Okukubo Memorial Fund for Medical Research in Kumamoto University School of Medicine.
Cell cultures. KP-1 was derived from the peripheral blood of a 2-y-old Japanese girl who was refered to Kumamoto University Hospital because of extensive swelling of the gingiva and bleeding from the mucosa of the oral cavity in October 1986. The white 
blood cell count of the peripheral blood was $64500 / \mu \mathrm{L}$ at admission and $80 \%$ of the cells were monoblasts. The leukemic cells were positive for $\alpha$-naphtyl butyrate esterase, which was inhibited by $\mathrm{NaF}$. Lysozyme activity in blood was increased to $90 \mathrm{mg} / \mathrm{L}$. Cell surface marker analysis by flow cytometry revealed that the blasts were positive for the MAb that recognize CD13, $\mathrm{CD} 14$, and CD33, but T-lymphocyte antigens (CD2, CD3) and B-lymphocyte antigens (CD19, CD20) were negative. The monoblasts were isolated from the peripheral blood by Ficoll-Hypaque density gradient centrifugation and cultured in RPMI 1640 medium (Gibco, Grand Island, NY) supplemented with $10 \%$ FBS (Gibco) in a humidified $5 \% \mathrm{CO}_{2}$ atmosphere. The medium was changed once a week, and after 2 mo the cells began to proliferate constantly with a doubling time of $96 \mathrm{~h}$. This cell line was stable and no morphologic, cytochemical, and surface marker changes were observed after $10 \mathrm{mo}$.

Cytologic and cytochemical studies. Morphologic characteristics of the cultured cells were examined by May-GruenwaldGiemsa staining of a cytocentrifuged preparation of the cells. $\alpha$-Naphtyl butylate esterase, napthol AS-D chloroacetate esterase, periodic acid-Schiff, and myeloperoxidase staining of the cultured cells were performed by the established methods (9-11).

Cell surface marker. The expression of cell surface antigens were analyzed by using MAb, OKT3 (CD3), OKT4 (CD4), OKT8 (CD8), OKIal (HLA-DR) (Ortho Diagnostic, Raritan, NJ), B1 (CD20), B4 (CD19), MY7 (CD13), MY4 (CD14), MY9 (CD33), Mol (CD11) (Coulter Immunology, Hialeah, FL), and LFA-1 $\alpha$ (CD1 1a), Leu M5 (CD11c), and LFA-1 $\beta$ (CD18) (Beckton Dickinson Immunocytometry Systems, Mountain View, CA). Cells were incubated with each MAb for $30 \mathrm{~min}$ at $4^{\circ} \mathrm{C}$, washed with cold PBS, and incubated with FITC-labeled goat antimouse IgG antibody (Ortho Diagnostic) for $30 \mathrm{~min}$ at $4^{\circ} \mathrm{C}$. Then the cells were washed and subjected to flow cytometry (Spectrum III, Ortho Diagnostic).

Karyotype analysis. Karyotype of the established cell line was examined by a standard trypsin-Giemsa banding.

Lysozyme. Cells $\left(5 \times 10^{7}\right.$ cells/L) were cultured in RPMI 1640 medium supplemented with $10 \%$ FBS for $3 \mathrm{~d}$. Then the cells were centrifuged and the supernatant was passed through a 0.45 $\mu \mathrm{m}$ Millipore filter. Lysozyme activity in culture supernatant was assayed by the turbidimetric technique.

Phagocytosis. A 1.0-mL suspension of $2 \times 10^{5} \mathrm{KP}-1$ cells was tested for phagocytic activity by incubation for $60 \mathrm{~min}$ at $37^{\circ} \mathrm{C}$ with a $1.0-\mu \mathrm{m}$ diameter latex particle (Sekisui Chemical Industry, Osaka, Japan). Furthermore, to evaluate the active phagocytosis via $\mathrm{Fc}$ receptor, the latex particle was opsonized by incubation with normal human serum at $37^{\circ} \mathrm{C}$ for $60 \mathrm{~min}$. The cells were smeared on slide glass and stained with May-Giemsa. Two hundred cells were examined for phagocytic activity.

Immunoelectron microscopy. Generation of anti-human scavenger receptor antibodies and immunostaining were performed by methods reported previously (7). Briefly, antibodies against the scavenger receptor were obtained by s.c. injection of $500 \mu \mathrm{g}$ of BSA-coupled synthetic peptide emulsified in Freund's complete adjuvant into 2 -mo-old male rabbits (Csk:JW/Ina). The synthetic peptides correspond to the sequence in the $\alpha$-helical coiled coil domain (residue 199-209) and the collagenous domain (325-342) of the type I scavenger receptor. The cell pellet of TPA-treated KP-1 cells was fixed for $10 \mathrm{~min}$ in $2 \%$ periodatelysine-paraformaldehyde solution. Then the specimens were incubated with antisera at a dilution of 1:800 to 1:1200. After being washed in PBS, the specimens were covered with goat antirabbit Ig conjugated with peroxidase (Amersham, Buckinghamshire, UK). Peroxidase activity was visualized using 3-3'-diaminobenzidine as substrate. Postfixation by osmium tetroxide, dehydration, and embedding were performed by standard procedures. Ultrathin sections were made by an Ultrotome NOVA (LKB, Uppsala, Sweden) and observed through a JEM 2000 EX electron microscope (JEOL, Tokyo, Japan).
Cellular mass of free cholesterol and CE. KP-1 and THP-1 (purchased from American Type Culture Collection, Rockville, MD) were cultured in the presence of TPA for $24 \mathrm{~h}$ and then various concentrations of aLDL were loaded. In a preliminary study, maximal accumulation of CE was observed in $20 \mu \mathrm{g} / \mathrm{L}$ TPA for KP-1 and $200 \mu \mathrm{g} / \mathrm{L}$ for THP-1 in the presence of 50 $\mathrm{mg} / \mathrm{L}$ aLDL. Thereafter, these concentrations of TPA were used for $\mathrm{CE}$ accumulation experiments in the two cell lines. The mass of free and esterified cholesterol was quantitated by the method reported by Heider and Boyett (12) with slight modifications. Briefly, aliquots $(10 \mu \mathrm{L})$ of lipid extract were incubated with 0.4 $\mathrm{mL}$ of enzyme mixture at $37^{\circ} \mathrm{C}$ for $1 \mathrm{~h}$ (for free cholesterol) and $2 \mathrm{~h}$ (for total cholesterol). Carbowax-6000 in the enzyme mixtures described by Heider and Boyett was changed to $0.01 \%$ Triton X-100 and enzymes with 2-fold higher concentrations (cholesterol oxidase: $160 \mathrm{U} / \mathrm{L}$; cholesterol hydrolase: $6000 \mathrm{U} / \mathrm{L}$ ) were used in this study. Fluorescence intensity was measured with excitation at $320 \mathrm{~nm}$ and emission at $407 \mathrm{~nm}$, and the amount of free and total cholesterol was calculated from the standard curves obtained by cholesterol $(0-8 \mathrm{nmol})$ and cholesterol oleate $(0-10 \mathrm{nmol})$ for free and total cholesterol, respectively. The amount of $C E$ was calculated by subtracting the amount of free from total cholesterol. The amount of protein of the samples was determined by the method reported previously (13).

Lipoprotcins. Human LDL (density $=1.019-1.063$ ) were prepared by sequential ultracentrifugation from the plasma of healthy volunteers. aLDL was prepared by the method reported by Basu et al. (14). aLDL was labeled with ${ }^{125}$ I (New England Nuclear Corp., Boston, MA) with Iodogen (BioRad Laboratories, Richmond, CA) to a specific radioactivity of $200 \mathrm{cpm} / \mathrm{ng}$. More than $98 \%$ of the labeled ligand was trichloroacetic acidprecipitable.

Association of ${ }^{125}$ I-labeled aLDL. KP-1 was seeded in plastic culture wells (Corning, Iwaki glass, Tokyo, Japan; $16 \mathrm{~mm}$ in diameter) at a concentration of $1.0 \times 10^{10}$ cells $/ \mathrm{L}$ in $1.0 \mathrm{~mL}$ of RPMI 1640 medium supplemented with $10 \%$ FBS plus $20 \mu \mathrm{g} / \mathrm{L}$ TPA and cultured for $24 \mathrm{~h}$ in a $5 \%$ humidified $\mathrm{CO}_{2}$ atmosphere at $37^{\circ} \mathrm{C}$. The monolayers were washed three times with $1.0 \mathrm{~mL}$ of Eagle's minimum essential medium (Gibco) containing 3\% BSA (Fraction V, Sigma Chemical Co., St. Louis, MO) buffered with $20 \mathrm{mM} N$-2-hydroxyethylpiperazine- $N^{\prime}$-2-ethanesulfonic acid (Sigma) to pH 7.4 (medium A). Each well was incubated at $37^{\circ} \mathrm{C}$ with varying concentrations of ${ }^{125}$ I-labeled aLDL in $0.5 \mathrm{~mL}$ of medium A. After $4 \mathrm{~h}$ of incubation, adherent cells were washed three times with $1.0 \mathrm{~mL}$ of medium $A$ and five times with PBS. Cells were dissolved for $3 \mathrm{~h}$ at $37^{\circ} \mathrm{C}$ in $1.0 \mathrm{~mL}$ of $0.1 \mathrm{~N} \mathrm{NaOH}$ to determine the cell-associated radioactivity. Nonspecific cellular association was determined by parallel culture with $1.0 \mathrm{~g} / \mathrm{L}$ of cold ligand. Specific cellular association was determined by subtracting nonspecific from total cell association.

Monokine production. The concentrations of TNF- $\alpha, \mathrm{IL}-1 \alpha$, IL- $1 \beta$, and M-CSF were determined by specific immunoassay in the culture media from 1) unstimulated, 2) TPA-stimulated, and 3) aLDL-loaded KP-1 cells. The enzyme immunoassay kits for TNF $-\alpha$, IL- $1 \alpha$, and IL- $1 \beta$ were purchased from Otsuka Pharmaceutical Co., Ltd. (Tokyo, Japan).

The method for enzyme immunoassay for M-CSF was described previously (15). The unstimulated cells were cultured at a concentration of $1.0 \times 10^{9}$ cells/ $\mathrm{L}$ in RPMI 1640 medium supplemented with $10 \%$ FBS and TPA-stimulated cells were cultured in the same medium in the presence of $20 \mu \mathrm{g} / \mathrm{L} \mathrm{TPA}$ for $48 \mathrm{~h}$. The aLDL-loaded cells were cultured with $20 \mu \mathrm{g} / \mathrm{L}$ TPA for the first $24 \mathrm{~h}$ and then cultured in the presence of 50 $\mu \mathrm{g} / \mathrm{L}$ of aLDL for an additional $24 \mathrm{~h}$. The culture supernatants were centrifuged at $1200 \mathrm{rpm}$ for $10 \mathrm{~min}$, passed through a 0.45 $\mu \mathrm{m}$ Millipore filter, and subjected to each immunoassay. 


\section{RESULTS}

Cytologic and cytochemical characteristics of KP-1 cells. KP-1 cells were homogenous suspension cells with an average doubling time of $96 \mathrm{~h}$. The cells were round and had membrane ruffles or pseudopods. They had a round nucleus with fine chromatin distribution and two to four nucleoli. The basophilic cytoplasm contained some granules. After treatment by $20 \mu \mathrm{g} / \mathrm{L}$ TPA, this cell line became tightly adherent to plastic surfaces within $24 \mathrm{~h}$. These cells were flat, had a reduced nuclear/cytoplasmic ratio, and had multiple projections on their surface membranes. There was a marked increase of vacuoles in cytoplasm and the granules were less prominent (Fig. $1 A$ and $B$ ). Mitotic figures, which were frequently observed in untreated KP-1 cells, were never seen after TPA treatment. Cytochemically, more than $90 \%$ of TPAstimulated cells showed intense cytoplasmic staining for $\alpha$-naphtyl butyrate esterase, which was completely inhibited by $\mathrm{NaF}$, whereas about $60 \%$ of the nonstimulated cells were less intensely stained for this enzyme. Naphthol AS-D chloroacetate esterase, myeloperoxidase, and periodic acid-Schiff staining were negative before and after TPA treatment.

Foam cell formation. When KP-1 cells were preincubated with $20 \mu \mathrm{g} / \mathrm{L}$ of TPA for $12 \mathrm{~h}$ and then cultured in the presence of 20-100 mg/L aLDL for an additional $24 \mathrm{~h}$, the cells were transformed into typical foam cells that contained many lipid droplets (Fig. 1C). The size and number of lipid droplets increased in parallel with the concentration of aLDL added. On the other hand, without TPA stimulation the cells were not transformed into foam cells in the presence of aLDL.

Surface marker analysis. The results of the surface marker analysis are summarized in Table 1. The KP-1 cells expressed the antigens that were recognized by OKT4 (CD4), MY7 (CD13), MY4 (CD14), MY9 (CD33), LFA-1 $\alpha$ (CD11a), Leu M5 (CD11c), LFA-1 $\beta$ (CD18), and OKIal (HLA-DR). This cell line did not react with the MAb that recognize T (CD 2, CD 3, CD 8 ) and $\mathrm{B}(\mathrm{Cd} 19, \mathrm{CD} 20)$ lymphocytes, showing that the binding of the cell line to the above-mentioned MAb was not due to nonspecific binding to $\mathrm{Fc}$ receptor (Table 1).

Karyotype analysis. Chromosome analysis of 10 cells showed near diploidy (modal chromosome number 47, range 46-48). A translocation $\mathrm{t}(11 ; 19)$ and other abnormalities, $1 \mathrm{p}^{-}, 10 \mathrm{p}^{+}, 16 \mathrm{q}^{+}$ and $19 \mathrm{p}^{+}$, were commonly observed (Fig. 2).
Ly'sozyme production. When KP-1 cells $\left(5 \times 10^{7}\right.$ cells $\left./ \mathrm{L}\right)$ were cultured in RPMI 1640 medium supplemented with $10 \%$ FBS for $3 \mathrm{~d}$, lysozyme activity in the culture supernatant was $2.0 \mathrm{mg} /$ L. The detection limit of this assay was $0.05 \mathrm{mg} / \mathrm{L}$ and the lysozyme activity in fresh culture medium was undetectable.

Phagocytosis. The percent phagocytosis of unopsonized particle in unstimulated and TPA-stimulated $(20 \mu \mathrm{g} / \mathrm{L}$, for $24 \mathrm{~h})$ cells was 3 and $12 \%$, respectively. When opsonized particle was used, the percent phagocytosis in unstimulated and stimulated cells increased to 13 and $46 \%$, respectively.

Expression of scavenger receptor in KP-1 cells. Immunoelectron microscopy showed positive staining on the cell surface membrane and occasionally on the membrane of the endocytic vesicles in the TPA-stimulated KP-1 cells, whereas the unstimulated cells showed no positive reactions (Fig. 3).

Endocytic uptake of aLDL by KP-1 cells. When KP-1 cells were stimulated by $20 \mu \mathrm{g} / \mathrm{L}$ TPA for $24 \mathrm{~h}$, cell-associated ${ }^{125} \mathrm{I}$ aLDL exhibited a typical saturation curve against the ligand concentration (Fig. 4). Furthermore, the addition of excess unlabeled ligand decreased the amount of cell-associated ${ }^{125} \mathrm{I}$-aLDL by $80 \%$. With the Scatchard analysis, the specific cell-associated ${ }^{125} \mathrm{I}$-aLDL gave an apparent $\mathrm{k}_{\mathrm{d}}$ for uptake of $1.7 \times 10^{-7} \mathrm{M}$ and 3400 binding sites per cell. These results demonstrated the presence of specific receptors for aLDL on the cell surface of the KP1 cells.

Accumulation of CE in KP-I cells loaded with aLDL and native $L D L$. When KP-1 cells were stimulated by $20 \mu \mathrm{g} / \mathrm{L}$ TPA for $24 \mathrm{~h}$ and then loaded with aLDL for an additional $24 \mathrm{~h}$, the amount of accumulated CE increased in parallel with the concentration of aLDL loaded. Approximately nine times the baseline $C E$ was accumulated when $100 \mathrm{mg} / \mathrm{L}$ aLDL were loaded. When native LDL was used, only a slight increase of CE accumulation was observed at 25 and $50 \mathrm{mg} / \mathrm{L}$ loading (Table 2). This result indicated that the stimulated KP-1 cells accumulated a large amount of $C E$ via scavenger receptor, but not via $L D L$ receptor. The unstimulated cells did not accumulate a significant amount of $\mathrm{CE}$ in the presence of aLDL (data not shown).

Comparison of time course CE accumulation between KP-I and THP-1 cells. KP-1 and THP-1 cells were differentiated by 24-h culture in RPMI 1640 medium supplemented with $10 \%$ FBS in the presence of $20 \mu \mathrm{g} / \mathrm{L}$ TPA for KP-1 cells and $200 \mu \mathrm{g} /$ $\mathrm{L}$ TPA for THP-1 cells. Then $50 \mathrm{mg} / \mathrm{L}$ aLDL was loaded and

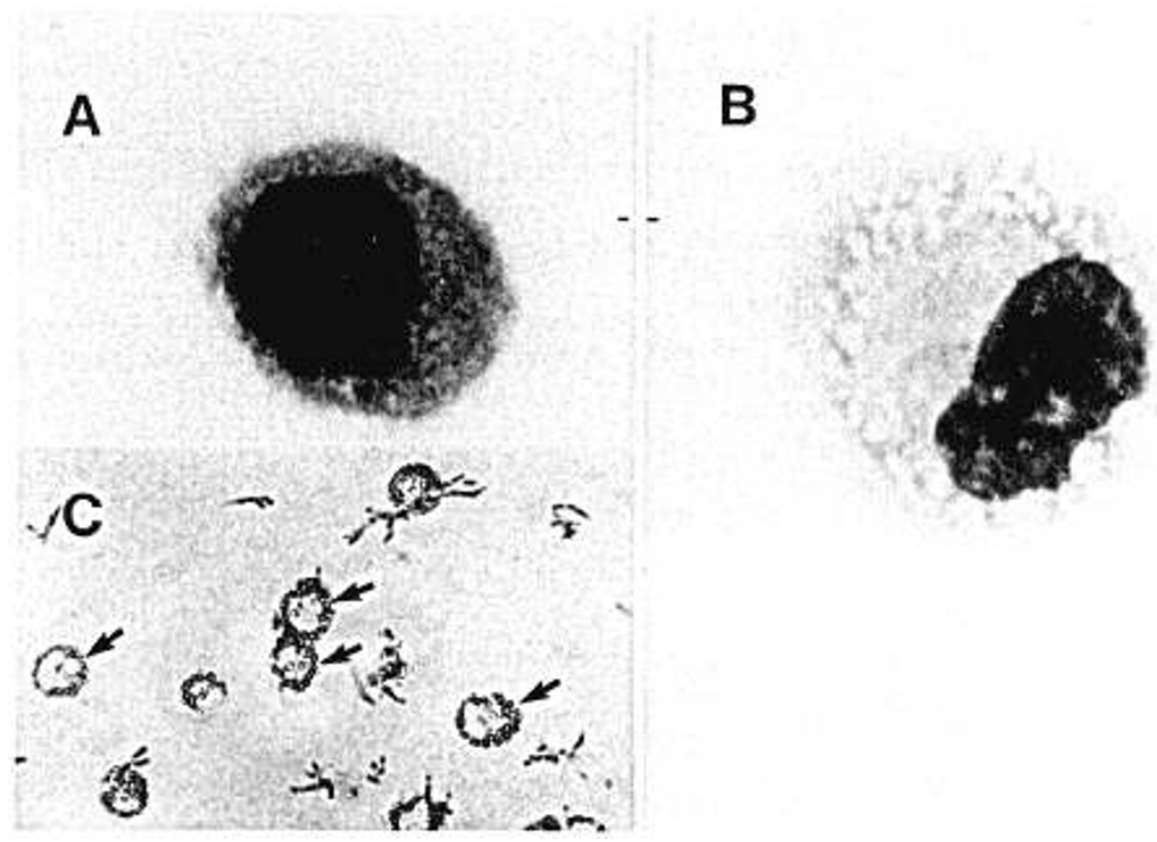

Fig. 1. Light microscopic photographs of unstimulated $(A)$ and TPA-stimulated $(B)(20 \mu \mathrm{g} / \mathrm{L}$, for $24 \mathrm{~h}) \mathrm{KP}-1$ cells stained with May-Giemsa staining $(\times 1000)$ and foam cells stained with Sudan III $(C)(\times 400)$. Arrow's indicate the typical foam cells. 
Table 1. Reactivity of KP-1 with $M A B$

\begin{tabular}{lc}
\hline Antigen & Positive cell $(\%)$ \\
\hline CD 2 & $(-)^{*}$ \\
CD 3 & $(-)$ \\
CD 4 & 80.4 \\
CD 8 & $(-)$ \\
CD 11a & 35.9 \\
CD 11c & 91.2 \\
CD 13 & 92.0 \\
CD 14 & 84.1 \\
CD 18 & 66.2 \\
CD 19 & $(-)$ \\
CD 20 & $(-)$ \\
CD 33 & 76.6 \\
HLA-DR & 81.5 \\
\hline
\end{tabular}

* Positive cells were less than $5 \%$.

time course of $C E$ accumulation in both cell lines was obtained. In KP-1, a significant amount of CE accumulation was observed in $24 \mathrm{~h}$ and the amount rapidly increased in parallel with the time course and reached maximum in $72 \mathrm{~h}$ after aLDL loading. In contrast, THP-1 accumulated CE very slowly for the first 48 $\mathrm{h}$ and the amount increased rapidly after $72 \mathrm{~h}$. The difference of maximal amount of $C E$ accumulated was not significant between the two cell lines (Fig. 5).

Monokine production. TNF- $\alpha$, IL- $1 \alpha$, IL- $1 \beta$, and M-CSF were below detection limit in culture supernatant from unstimulated $\mathrm{KP}-1$ cells. When KP-1 cells were stimulated by $20 \mu \mathrm{g} / \mathrm{L}$ TPA, the concentration of TNF- $\alpha$, IL- $1 \beta$, and M-CSF increased to $11.3 \mathrm{ng} / \mathrm{L}, 25.0 \mathrm{ng} / \mathrm{L}$, and $8600 \times 10^{3} \mathrm{U} / \mathrm{L}$, respectively. After $\mathrm{KP}-1$ cells were transformed into foam cells, the concentration of TNF- $\alpha$, IL- $1 \beta$, and M-CSF further increased to $25.2 \mathrm{ng} / \mathrm{L}$, $49.0 \mathrm{ng} / \mathrm{L}$, and $9800 \times 10^{3} \mathrm{U} / \mathrm{L}$, respectively. IL- $1 \alpha$ was not detected in any samples (Table 3 ).

\section{DISCUSSION}

The present report described the establishment and characterization of a novel human monocytic leukemia cell line, KP-1, which was derived from a 2-y-old Japanese girl with acute monocytic leukemia. This cell line showed the following characteristics: 1 ) the presence of $\alpha$-naphtyl butylate esterase, which was inhibited by $\mathrm{NaF}$; 2) lysozyme production; 3) phagocyte activity of the latex particle; 4) expression of CD13, CD14, CD33, CD11a, CD11 c, CD18, and HLA-DR antigens on the cell surface; 5 ) production of several monokines, TNF- $\alpha$, IL- $1 \beta$, and M-CSF, after TPA treatment; 6 ) induction of scavenger receptor expression after TPA treatment; and 7) accumulation of a large amount of $\mathrm{CE}$ and transformation into foam cells in the presence of TPA and aLDL. These results demonstrated that this cell line represents a monocyte-macrophage lineage cell and can be differentiated into mature macrophage-like cells after TPA treatment.

Macrophage scavenger receptors are implicated in the pathologic deposition of cholesterol in arterial walls. The expression of scavenger receptor in the present cell line was demonstrated by immunostaining using the antibodies against human macrophage scavenger receptor, but its expression was limited to the differentiated cells. This result was compatible with the observation that only the differentiated cells accumulated a large amount of $\mathrm{CE}$ in the presence of aLDL, confirming that the uptake of aLDL was made via scavenger receptor. The immunostaining demonstrated that cell surface membrane and occasionally membrane of the endocytic vesicles were positively stained, indicating that the uptake was made by invagination of cell surface membrane and subsequent endocytic vesicle formation. Scatchard analysis using ${ }^{125} \mathrm{I}-\mathrm{aLDL}$ revealed that the apparent $\mathrm{k}_{\mathrm{d}}$ for uptake was $1.7 \times 10^{-7} \mathrm{M}$ and the number of binding sites per cell was 3400 . These values were similar to those of another monocytic leukemia cell line, THP-1, which also expresses the scavenger receptor after differentiation and accumulates a large amount of CE in the presence of aLDL (16).

Among several human cell lines representing macrophage characteristics, THP-1 and U-937 were often used as an in vitro model for foam cells in atherosclerotic lesions (17-21). THP-1 and U-937 were established from a patient with acute monocytic leukemia and one with histiocytic lymphoma, respectively $(22$, 23). However, there are some differences in the pathway and the time course of the accumulation of CE between the cell lines. U937 accumulates $C E$ via both the scavenger and the LDL receptor pathway (24), whereas THP-1, KP-1, and monocyte-derived

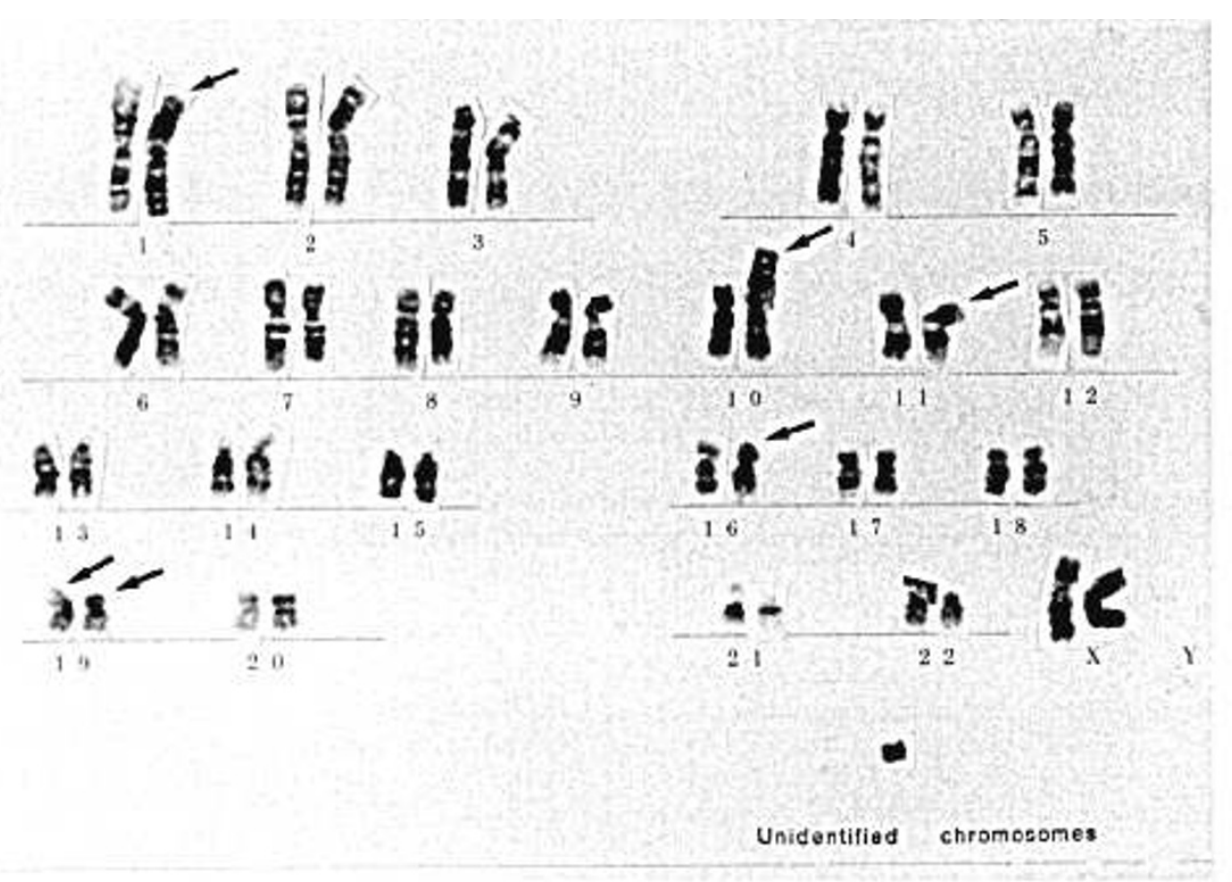

Fig. 2. The representative karyotype of KP-1, showing $47 \mathrm{XX}, \mathrm{t}\left(11 \mathrm{q}^{+} ; 19 \mathrm{p}^{-}\right), 1 \mathrm{p}^{-}, 10 \mathrm{p}^{+}, 16 \mathrm{q}^{+}, 19 \mathrm{p}^{+},+$mar. Arrows indicate the translocated chromosomes. 

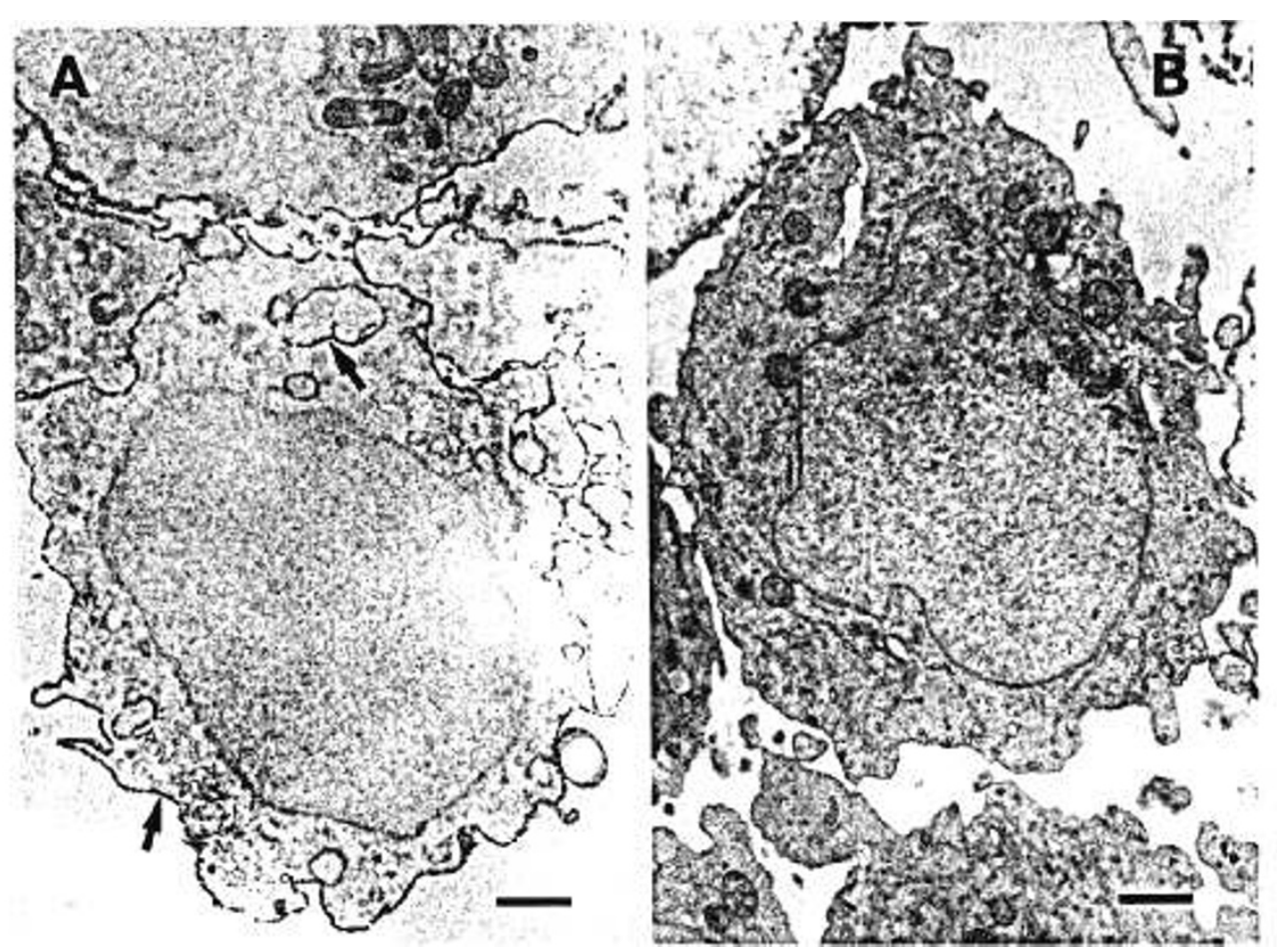

Fig. 3. Electron microscopic photograph of KP-1 immunostained with the antibodies against human macrophage scavenger receptor. Positive staining (arrows) is found in the cell surface membrane and the membrane of endocytic vesicles in TPA-stimulated cells $(A, \times 8800)$. In contrast, no positive staining is found in unstimulated cells $(B, \times 9800)$.

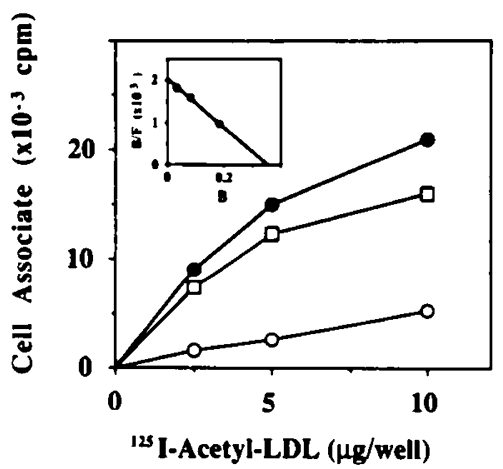

Fig. 4. Cell-associated ${ }^{125} \mathrm{I}-\mathrm{aLDL}$ as a function of ligand concentrations in KP-1. Cells were incubated with ${ }^{125} \mathrm{I}$-aLDL in the presence (nonspecific cell-association, $O$ ) or absence (total cell association, $\bullet$ ) of $1 \mathrm{mg} / \mathrm{mL}$ unlabeled aLDL. $\square$ denotes the specific uptake and Scatchard analysis is shown in the inset.

macrophage accumulate $\mathrm{CE}$ only from the scavenger receptor pathway after differentiation (17). Compared with widely used THP-1, KP-1 showed a very distinct time course of CE accumulation. As shown in Figure 5, KP-1 accumulated a large amount of CE much more rapidly than THP-1. This result indicated that the functional expression of the scavenger receptor was induced more rapidly in KP-1 than in THP-1. In fact, as Via et al. (25) reported that the scavenger receptor expression of THP-1 cells reaches optimal levels after $72 \mathrm{~h}$ of TPA treatment and the delayed expression of the scavenger receptor is one of the possible explanations for the delayed accumulation of $\mathrm{CE}$ in THP-1 cells. These characteristics of KP-1 may be practically important and may facilitate the in vitro studies of scavenger receptor function and the mechanism of foam cell formation.

Another characteristic of KP-1 cells is that this cell line retains the capacity to produce several monokines, TNF- $\alpha$, IL- $1 \beta$, and M-CSF. This cell line produced these monokines after differentiation by TPA. It is of interest to note that the monokine
Table 2. Cellular mass quantitation of total cholesterol, free cholesterol, and cholesterol esters in KP-1 loaded with aLDL and native $L D L^{*}$

\begin{tabular}{ccccc}
\hline $\begin{array}{c}\text { Treatment } \\
(\mu \mathrm{g} / \text { well) } \text { (nmol/mg } \\
\text { cell protein) }\end{array}$ & $\begin{array}{c}\text { FC (nmol/ } \\
\text { cell protein) }\end{array}$ & $\begin{array}{c}\text { CE (nmol/mg } \\
\text { cell protein) }\end{array}$ & $\begin{array}{c}p \\
\text { value }\end{array}$ \\
\hline aLDL & & & & \\
0 & $94.16 \pm 9.61$ & $85.51 \pm 9.52$ & $8.65 \pm 1.47$ & \\
25 & $147.30 \pm 7.39$ & $106.76 \pm 3.06$ & $40.54 \pm 4.33<0.001$ \\
50 & $171.36 \pm 12.14$ & $111.47 \pm 8.13$ & $60.16 \pm 4.33<0.001$ \\
100 & $177.24 \pm 7.15$ & $100.10 \pm 4.35$ & $77.14 \pm 2.94<0.001$ \\
LDL & & & & \\
0 & $94.86 \pm 2.57$ & $85.93 \pm 2.90$ & $8.93 \pm 0.78$ \\
25 & $100.58 \pm 6.24$ & $89.10 \pm 5.93$ & $11.48 \pm 0.32<0.05$ \\
50 & $105.13 \pm 3.35$ & $87.61 \pm 3.37$ & $17.51 \pm 3.02<0.05$ \\
100 & $89.04 \pm 3.47$ & $79.09 \pm 2.67$ & $12.95 \pm 3.99$ & NS \\
\hline
\end{tabular}

* Results are expressed as mean \pm SEM of triplicate assays and the increase in the accumulated amount of $C E$ was statistically evaluated by using the paired $t$ test. TC, total cholesterol; FC, free cholesterol; and $\mathrm{CE}$, cholesterol esters.

production was further augmented along with the transformation of this cell line into foam cells (Table 3). TNF- $\alpha$ and IL- $1 \beta$ have been suggested as the potential enhancer of the atherosclerotic lesions. These monokines stimulate PDGF production from endothelial cells and smooth muscle cells $(26,27)$. PDGF from endothelial cells may induce migration of smooth muscle cells into the atherosclerotic lesion and PDGF production from smooth muscle cell may stimulate its own proliferation by autocrine mechanism. The accumulation of smooth muscle cells leads the early stage of atherosclerotic lesions to more advanced plaques. Furthermore, several investigators have reported that both monokines induce expression of leukocyte adhesion molecules on the surface of endothelial cells $(28,29)$. Therefore, these monokines will enhance the infiltration of leukocytes into the atherosclerotic lesion, which will accelerate the atherosclerotic process. With respect to M-CSF, this monokine can also be atherogenic by enhancing the expression of scavenger receptor 


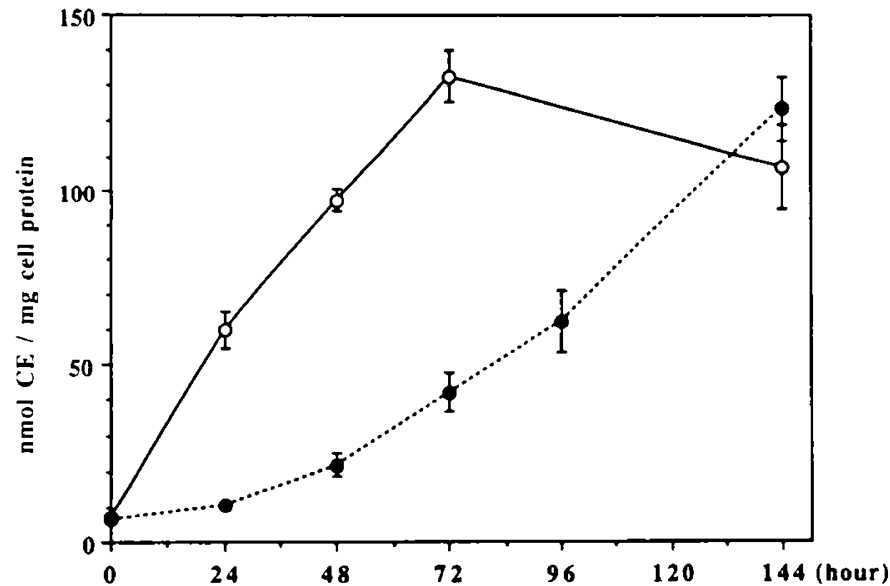

Fig. 5. Comparison of time course for $\mathrm{CE}$ accumulation between THP-1 and KP-1. THP-1 $(\bullet)$ and KP-1 $(\mathrm{O})$ were incubated for $24 \mathrm{~h}$ with 200 and $20 \mu \mathrm{g} / \mathrm{L}$ TPA, respectively. Then $50 \mathrm{mg} / \mathrm{L}$ aLDL was loaded and the accumulated amount of cholesterol ester was quantitated at the time point indicated for an additional $24 \mathrm{~h}$. Each value is expressed as mean \pm SEM of triplicate assays.

Table 3. Effect of TPA and aLDL loading on monokine production from $K P-I^{*}$

\begin{tabular}{cccc}
\hline & \multicolumn{3}{c}{ Monokine } \\
\cline { 2 - 4 } Treatment & $\begin{array}{c}\text { TNF- } \alpha \\
(\mathrm{ng} / \mathrm{L})\end{array}$ & $\begin{array}{c}\mathrm{IL}-1 \beta \\
(\mathrm{ng} / \mathrm{L})\end{array}$ & $\begin{array}{c}\mathrm{M}-\mathrm{CSF} \\
\left(\mathrm{U} \times 10^{-3} / \mathrm{L}\right)\end{array}$ \\
\hline No treatment & UD & UD & UD \\
TPA & 11.3 & 25.0 & 8800 \\
TPA + aLDL & 25.2 & 49.0 & 9900 \\
\hline
\end{tabular}

* Results are expressed as mean of duplicate assays. Detection limits of TNF- $\alpha$, IL- $1 \beta$, and M-CSF were $2 \mathrm{ng} / \mathrm{L}, 4 \mathrm{ng} / \mathrm{L}$, and $50 \times 10^{3} \mathrm{U} / \mathrm{L}$, respectively. UD, undetectable.

and the uptake of cholesterol $(30,31)$. Therefore, these lines of evidence suggest that foam cell formation could further accelerate the atherosclerotic process via augmented production of the monokines.

The expression of macrophage functions is closely related to the differentiation stage. Complement production, cytotoxic activity, phagocytic activity, chemotactic responses, and the production of mediators of inflammation have all been shown to be maximally expressed at specific stages of differentiation $(32,34)$. Therefore, it would be necessary to prepare homogenous macrophages in the same differentiation stage to investigate their functions. In this sense, the present cell line, being homogenous in the differentiation stage and expressing scavenger receptors by short-term incubation with TPA will be useful and facilitate in vitro studies of the pathologic and physiologic functions of macrophages via scavenger receptors.

Acknowledgments. The authors thank Dr. T. Kodama of the University of Tokyo for providing the antibodies against human macrophage scavenger receptor, Dr. N. Araki for experimental instructions, and $\mathrm{M}$. Ohara for critical reading of the manuscript.

\section{REFERENCES}

1. Vedeler CA, Nyland H, Matre R 1984 In situ characterization of the foam cells in early human atherosclerotic plaques. Acta Pathol Microbial Immunol Scand [C] 92:133-137

2. Agel NM, Ball RY, Waldman H, Mitchinson MJ 1984 Monocytic origin of foam cells in human atherosclerotic plaques. Atherosclerosis 53:265-271

3. Klurfeld DM 1985 Identification of foam cells in human atherosclerotic lesions as macrophages using monoclonal antibodies. Arch Pathol Lab Med 109:445-449

4. Goldstein JL, Ho YK, Waldman H, Brown MS 1979 Binding site on macrophages that mediates uptake and degradation of acetylated low density lipoprotein, producing massive cholesterol deposition. Proc Natl Acad Sci USA 76:333-337

5. Matsumoto A. Naito M, Itakura H, Ikemoto S, Asaoka H, Hayakawa I Kanamori H, Aburatani H, Takaku F, Suzuki H, Kobari Y, Miyai T, Takahashi K, Cohen EH, Wydro R, Housman DE, Kodama T 1990 Human macrophage scavenger receptors: Primary structure, expression and localization in atherosclerotic lesions. Proc Natl Acad Sci USA 87:9133-9137

6. Freeman M, Ekkel Y, Rohrer L, Penman M, Freedman NJ, Chisolm GM, Krieger M 1991 Expression of type I and type II bovine scavenger receptors in Chinese hamster ovary cells: lipid droplet accumulation and nonreciprocal cross competition by acetylated and oxidized low density lipoprotein. Proc Natl Acad Sci USA 88:4931-4935

7. Naito M. Suzuki H. Mori T, Matsumuto A, Kodama T, Takahashi K 1992 Coexpression of Type I and Type II human macrophage scavenger receptors in macrophages of various organs and foam cells in atherosclerotic lesions. Amer J Pathol 141:591-600

8. Hampton RY, Golenbock DT, Penman M, Krieger M, Raetz CRH 1991 Recognition and plasma clearance of endotoxin by scavenger receptors. Nature 352:342-344

9. Karpas A, Hayhoe FGJ, Greenberger JS, Barker CR, Cawley JC Lowenthal RM, Moloney WC 1977 The establishment and cytological, cytochemical and immunological characterization of human haemic cell line: evidence for heterogeneity. Leukemia Res 1:35-49

10. McManus JFA 1946 Histological demonstration of mucin after periodic acid. Nature 158:202

11. Kaplow LS 1975 Substitution for benzidine in myeloperoxidase stains. Am J Clin Med 65:451

12. Heider JG, Boyett RL 1978 The picomole determination of free and total cholesterol in cells in culture. J Lipid Res 19:514-518

13. Lowry OH, Rosebrough MJ, Farr AL, Randall RJ 1951 Protein measurement with Folin phenol reagent. J Biol Chem 193:265-275

14. Basu SK, Goldstein JL. Anderson RGW, Brown MS 1976 Degradation of cationized low density lipoprotein and regulation of cholesterol metabolism in homozygous familial hypercholesterolemia fibroblasts. Proc Natl Acad Sci USA 73:3178-3182

15. Hanamura T, Motoyoshi K, Yoshida K, Saito M, Miura Y, Kawashima T, Nishida M, Takaku F 1988 Quantitation and identification of human monocytic colony-stimulating factor in human serum by enzyme-linked immunosorvent assay. Blood 72:886-892

16. Bottalico LA, Wager RE, Agellon LB, Assoian RK. Tabas I 1991 Transforming growth factor- $\beta 1$ inhibits scavenger receptor activity in THP-1 human macrophages. J Biol Chem 266:22866-22871

17. Hara H, Tanishita H, Yokoyama S, Tajima S, Yamamoto A 1987 Induction of acetylated low density lipoprotein receptor and suppression of low density lipoprotein receptor on the cells of human monocytic leukemia cell line (THP-1 cell). Biochem Biophys Res Commun 146:802-808

18. Banka CL, Black AS, Dyer CA. Curtiss LK 1991 THP-1 cells form foam cells in response to coculture with lipoproteins but not platelets. J Lipid Res 32:35-43

19. Yamamoto A, Takaichi S, Hara H. Nishikawa O, Yokoyama S, Yamamura T, Yamaguchi T 1986 Probucol prevents lipid storage in macrophages. Atherosclerosis 62:209-217

20. Sacks FM, Breslow JL 1987 Very low density lipoproteins stimulate cholestery ester formation in U937 macrophages. Heterogeneity and biologic variation among normal humans. Arteriosclerosis 7:35-46

21. Mendelsohn ME, Loscalzo J 1988 Role of platelets in cholesteryl ester formation by U-937 cells. J Clin Invest 81:62-68

22. Tsuchiya S, Yamabe M, Yamaguchi Y, Kobayashi Y, Konno T, Tada K 1980 Establishment and characterization of a human acute monocytic leukemia cell line (THP-1). Int J Cancer 26:171-176

23. Sundstrom C, Nilsson K 1976 Establishment and characterization of a human histiocyte cell line (U-937). Int J Cancer 17:565-577

24. Hayashi K. Dojo S, Ohtani H, Hirata Y, Nakashima K. Nishio E, Sacki M, Kurushima H, Horiuchi I, Kajiyama G 1990 Foam cell formation of macrophages and lipoprotein receptors; a contribution of LDL receptor and scavenger receptor. J Jpn Atheroscler Sci 18:819-822

25. Via DP, Pons L, Dennison DK, Fanslow AE, Bernini F 1989 Induction of acetyl-LDL receptor activity by phorbor ester in human monocyte cell line THP-1. J Lipid Res 30:1515-1524

26. Hajjar KA, Hajjar DP, Silverstein RL, Nachman RL 1987 Tumor necrosis factor-mediated release of platelet-derived growth factor from cultured endothelial cells. J Exp Med 116:235-245

27. Raines EW, Dower SK, Ross R 1989 Interleukin-1 mitotic activity for fibroblasts and smooth muscle cells is due to PDGF-AA. Science 243:393-396

28. Bevilacqua M, Pober JS, Mendrick DL, Cotran RS, Gimbrone Jr MA 1987 Identification of an inducible endothelial-leukocyte adhesion molecule. Proc Natl Acad Sci USA 84:9238-9242

29. Pober JS, Gimbrone Jr MA, Lapiere LA, Mendrick DL, Fiers W, Rothlein R Springer TA 1986 Overlapping patterns of activation of human endothelial 
cells by interleukin-1, tumor necrosis factor and immune interferon. $\mathbf{J}$ Immunol 137:1893-1896

30. Clinton SK, Underwood R, Hayes L, Sherman ML, Kufe DW, Libby P 1992 Macrophage colony-stimulating factor gene expression in vascular cells and in experimental and human atherosclerosis. Am J Pathol 40:301-316

31. Ishibashi S, Inaba T, Shimano H, Harada K, Inoue I, Mokuno H, Mori N, Gotoda T, Takaku F, Yamada N 1990 Monocyte colony-stimulating factor enhances uptake and degradation of acetylated low density lipoproteins and cholesterol esterification in human monocyte-derived macrophages. J Biol Chem 265:14109-14117
32. Alpert SE, Auerbach HS, Cole FS, Colten HR 1983 Macrophage maturation: Differences in complement secretion by marrow, monocyte, and tissue macrophages detected with an improved hemolytic plaque assay. J Immunol 130:102-107

33. Neumann C, Sorg C 1980 Sequential expression of functions during macrophage differentiation in murine bone marrow liquid cultures. Eur J Immunol 10:834-840

34. Sorg C 1982 Heterogeneity of macrophages in response to lymphokines and other signals. Mol Immunol 19:1275-1278

\section{Announcement}

\section{Research on Hair Testing for Drugs of Abuse}

The National Institute on Drug Abuse has an interest in research on the utility of hair as a specimen for the detection of drugs of abuse. The goals of this program are to encourage systematic research on the use of hair testing to detect drugs of abuse in an accurate and reliable manner and to develop the necessary procedures and safeguards. Specific areas of interest are pharmacologic studies, analytical studies, and cost/benefit ratio analyses. Further information may be obtained from Rao S. Rapaka, Ph.D., or M. Beth Grigson Babecki, M.A., Division of Basic Research, National Institute on Drug Abuse, 5600 Fishers Lane, Room 10A-31, Rockville, MD 20857, (301) 443-6975. (Program announcement no. PA-92-18, November 1, 1991-November 1, 1994) 